\title{
Changes in the anatomical structure of the shoot apex of To-pe-tsai (Brassica chinensis L.) during transition from the vegetative to the reproductive state and the determination of the bolting
}

\author{
Wang Po-Jen \\ Faculty of Agriculture, Nagoya University, Chikusa, Nagoya, Japan

\section{Summary}

An investigation was made of the anatomical structure of the shoot apex in To-pe-tsai (Brassica chinensis L.). It is found that the young apex has one tunica layer, and the zonation is not evident. The tunica layer increace to the maximum of $4-5$ when the apex becomes adult, and when tend to reproductive phase, the layer increase to 5-6, and then decrease rapidly to 3 before the lst flower primordium is initiated.

1 st to 4 th leaf primordia are initiated at the 2 nd layer of the peripheral zone by periclinal division, whereas 5 th to the terminal leaf (bract) are initiated from the $3 \mathrm{rd}$ layer, and are also by periclinal division. The floral primordia are initiated from 4 th layer constantly.

The upper internods elongation occure before the lst floral primordium is initiated. The first symptom of the bolting can be observed as a cell elongation at the subapical region.

\section{Introduction}

To-pe-tsai, a kind of chinese cabbage, is one of the most common vegetables grown in Formosa. It is charactarised on the high temperature resistance, early maturity and it's reproductive behavior sensitively appears to depend upon a lower temperature have discribed in an earlier report ${ }^{(15)}$.

The ontogenetic and histochemical changes in various plants during transition from the vegetative to the reproductive stage was already been reported by many workers ${ }^{(1,3,4,5,6,7,10)}$ and become frequently in recent years. Most workers, however, were concerned with the anatomical and histochemical changes in the photoperiodic sensitive plants such as Pharbitis nil ${ }^{(5,6,7)}$, Chenopodium album ${ }^{(3,4)}$, Amaranthus retroflexus ${ }^{(1)}$ and Xanthium pensyl vanicum ${ }^{(9)}$. Only a few workers are dealing with the chilling reqeirement of the rosette plant, such as Wheat plant $^{(10)}$.

It is author's intention to characterize the vegetative and inflorescence apices in Brassica chinensis, especialy on the anatomical changes of meristem in leaf initiation, flower formation and bolting.

\section{Material and methods}

Seedlings of To-pe-tsai were used during the course of these investigations. The seeds were spread on moist filter paper in petridish, kept at $25^{\circ} \mathrm{C}$. After 24 hours the seeds were swellen fully, and after 48 hours the main root grew about $1 \mathrm{~mm}$ in length. By this time, the germinated seed were selected uniformly and sown in a wooden box filled with garden soil in

\footnotetext{
Received for publication October 9, 1968
} 
the green house at temperatures varying from 20 to $30^{\circ} \mathrm{C}$. Shoot: samples were taken every day for the first 5 days and every 3-day there after till flowering. The seedlings were supplemented with $10 \mathrm{w} / \mathrm{m}^{2}$ artificial illumination (Vita-lux, NEC made) to effect a $16-\mathrm{hr}$ photoperiod. After 5 days, the cotyledons would have expanded fully, and after 12 days, the lst leaf grew about $1 \mathrm{~cm}$ in length. At this time, the seedlings were divided into two groups, one was chilled for 7 days at $4^{\circ} \mathrm{C}$ in dark, and the remaining seedlings were used as control, kept under the same conditions as they were planted. After 7 days chilling, they were put back to green house under the same conditions as control. For the anatomical studies, the samples were fixed in FAA (formalin-alcohol-acetic acid). After getting dehydrated and paraffin embeded, the tissues were cut into longitudinal and transverse sections at $8 \mu$, the former were stained with Ehrlich's Hematoxylin for the anatomical observation, and the later with $1 \%$ Erythrosin for counting the leaf number and the plastochrone interval determination.

\section{Observation}

\section{Vegetative apex :}

The apex of embryo is about $70 \mu$ in width and $30 \mu$ in height. They have one surface layer with the cells which are extremely large. The cells in apex are almost uniform isodiametric and are stained uniformly with Hematoxylin. Cytological zonation is not evident at this stage. A total of 80 cells are counted in one longitudinal section.

After $24 \mathrm{hr}$ of seed hydration, the seeds are increased in size and a crack appeared on the surface of the seed coat, The cells of the apex is still stained uniformly except the cells of lst layer near the summit which usually stained lightly and show relatively large nucleus (Fig. 4, arrow). The cells on the 2nd layer were corresponded on the inner side of these heavily stained cells, periclinal division occured as a result of the initiation of the 2nd leaf primordium. The cells in the subapical region are elongate with there periclinal dimension.

After $48 \mathrm{hr}$ of seed hydration, the apex becomes larger and the cell number are increased, whereas cell size is decreased. The meristem is surrounded by lst and 2nd leaf primordia. The 2nd layer becomes noticeable but not so markedly. At the cells on the lower part of 2nd layer, periclinal division occurs as a result of 3rd leaf formation (Fig. 5, the end of arrow). After periclinal division occurs at the 3rd layer, the cells on the lst and 2nd layers near these divided cells are stained strongly, less vacuole, and become mitotically active. Anticlinal cell division occurs at this area, thus a protuberance appears on the surface of the apex.

3 days after seed hydration, the apex is $100 \mu$ in width and $60 \mu$ in height. The zonation become very apparent as a result of the formation of 2 nd tunica layer. Cells of the both sides of the apex are usually stained strongly but the summit of the tunica cells are stained weakly. From the 3rd layer of the peripheral zone, periclinal cell division occurs ed as a result of initiation of 5 th leaf primordium.

After 8 days of seed hydration, the cotyledons are fully expanded, and the lst leaf can be observed by naked eye. The tunica have 3 clear layers. In longitudinal section, the cells of lst and 2nd layers are rectangular with their periclinal dimensions larger than the anticlinal. Cells of the tunica are generally larger than the cells of the underlying cell of corpus. Cell 
number is increased at the apex, a total of about 130 cells are counted in one longitudinal section. The cells at subapical region, they are elongated at the beginning of seed hydration, tend to be flat (Fig. 7).

After 17 to 26 days of seed hydration, the initiation of 8 th to 15 th leaf primordia can also be observed at the 3rd layer of peripheral zone. The apex is about $120 \mu$ in width and $75 \mu$ in height, and there are about 200 cells in one longitudinal section. 4 to 5 tunica layers are observed. The peripheral zone at the both sides of the apex are usually stained well by Hematoxylin.

If the plants were growing under the same conditions, the apex would have tend to show: reproductive phase after 30 to 50 days, and flowered after 50 to 70 days.

\section{Inflorescence apex :}

If the plants were chilled at $4^{\circ} \mathrm{C}$ for 7 days at one foliage leaf (about $1 \mathrm{~cm}$ length) stage, the apex would have tend to show reproductive phase 10 days after the end of chilling.

Before the apex is transformed into an inflorescence, the apex, increased in size, and the tunica layers are added to the total of 5 to 6 . The height of the apexis increased, and the diameteris decreased relatively (Fig. 9).

6 days after the end of chilling treatment, the cells of the apex, especially the tunnica layer and peripheral zone tend to become similar in size, stained uniformly and strongly. The: vacuoles become smoller and the cell division increased throughout the apex. But the greatest concentration of mitotic activity is in the cells at the peripheral zone and the upper part of the corpus. Then the apex gradually grew higher and thicker, thus the meristem no longer shows the zonation characteristic of the vegetative apex.

The first symptom of morphological change of bolting can be observed at the cells of the subapical region. At the vegetative stage, the subapical cells are flat in shape (Fig. 7 and 8 ), but the cell elongation occurred at the beginning of bolting. In longitudinal section, the cells in these areas become rectangular with their periclinal dimention larger than the anticlinal. Thus. causes internode elongation and become bolting (Fig. 2,9 and 10).

The 3rd leaf from the terminal is also initiated at the 3rd layer of peripheral zone (Fig. 10 and 11, lower arrow). The first flower primordia is initiated at the 4 th layer above the origin of leaf at the same node (Fig. 10 and 11, upper arrow). At the opposite side, the next leaf and floral primordia are also initiated at the 3rd and 4th layer respectivily. The terminal leaf and the 3rd flower are also initiated from the same layer.

When the apex tends to reproductive phase, the plastochron interval is decreased. The vegetative apex produces 0.25 leaf per day, while the reproductive apex produces 0.5 to 0.9 leaf (or bract) per day. The leaf primordium is stained strongly and is mitotically active.

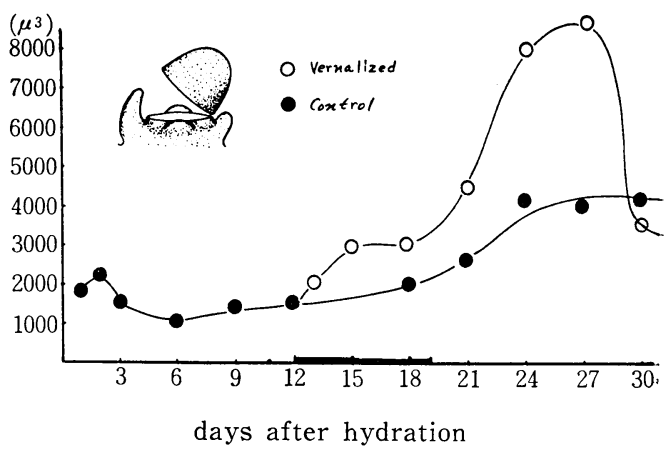

Fig. 1. Changes in the volume of apex during before and after the chilling treatment. A heavy line on the axis of abscissa is the period. of chilling treatment. 


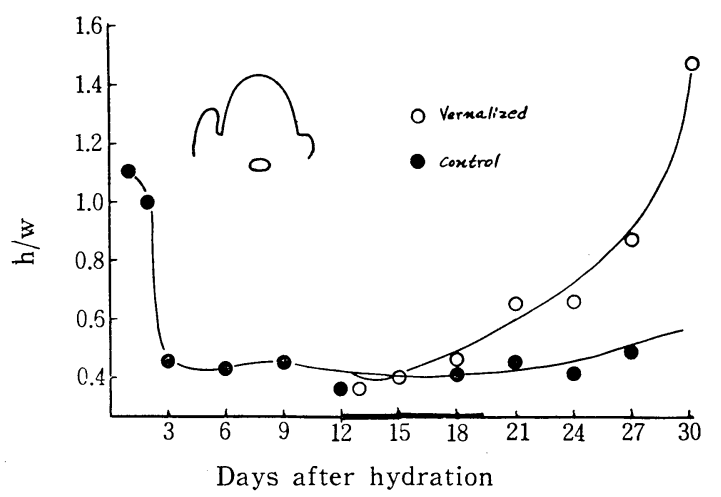

Fig. 2. The ratio of subapical cells between the height and width in longitudinal section of shoot apex during before and after the chilling treatment. The floral primordium is initiated at the 9 days after the end of chilling treatment (24 days after seed hydration).

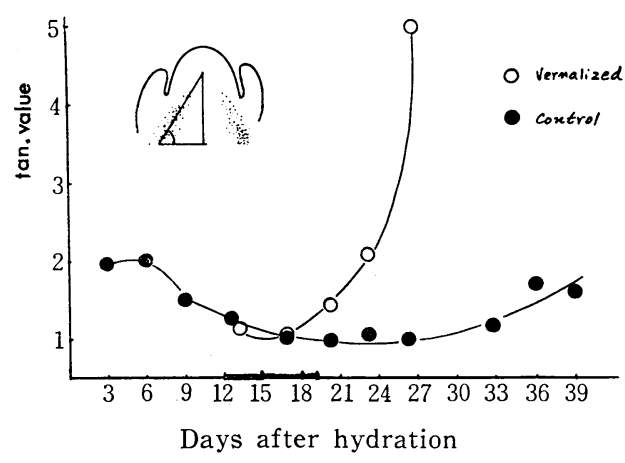

Fig. 3. Changes in the angle of procambium in subapical region during before and after the chilling treatment. The degree of the angles are represented by Tangental value.

\section{Discussion}

The apical meristem of chinese cabbage have a tunica corpus organization. This organization in angiosperms have been reported by many investigatores ${ }^{(2,3,8,9,11,12)}$. The apical meristem are already organized in seed, but the zonation is not evident at this stage. 3 days after hydration, the apex become very apparent. They have 2 tunica layers, and the peripheral zone are stained strongly by Hematoxylin. Above 17 days after hydration, the tunica layer had a maxi mum of 4 to 5 layers. The number of tunica layers keeps constant till the apex is tend to show transitional phase. The number of tunica layer increases from 5 to 6 at the transitional phase, and then decreases rapidly to $3-4$ before the lst flower bud is initi ated. The similar results have been reported by Gifford and Wetmore ${ }^{(3,8)}$.

It is of great interest that the lst to 4 th leaf primordia are initiated from 2 nd layer of the peripheral zone, while the 5 th to the terminal's are initiated from 3 rd layer of the same. They are also divided periclinally at the original cell division. The early symptoms of initiation of leaf and bract are generally similar. It is possible to conclude that the leaf primordia are initiated from the outer layer when the shoot meristem is still young, and from inner layer when develop into adult. Whether this differenece has arisen from the different kinds of plant is not yet completely clear.

The flower is initiated from the deeper part of the apex, and is also by periclinal division. Such results have also been reported by Satina in Datural ${ }^{(12)}$, Wang in Pharaenopsis ${ }^{16)}$, and Tepfer in Aquilegia Formosana ${ }^{(14)}$.

In agreement with Gifford et al in Chenopodium album ${ }^{(3)}$, and Schwabe in Chrysanthmum ${ }^{(13)}$, the author also observed that when the apex approaches the reproductive phase, the mitotic activity increases at the peripheral zone and the upper part of the corpus. Thuis causes the apex increase in size and shortens plastochron interval.

The mitotically active cells, such as cells of peripheral zone, contains a large nucleous and nucleoulus, heavily stained cytoplasm, less vacuole and the condriomes are punctuated. Wang 


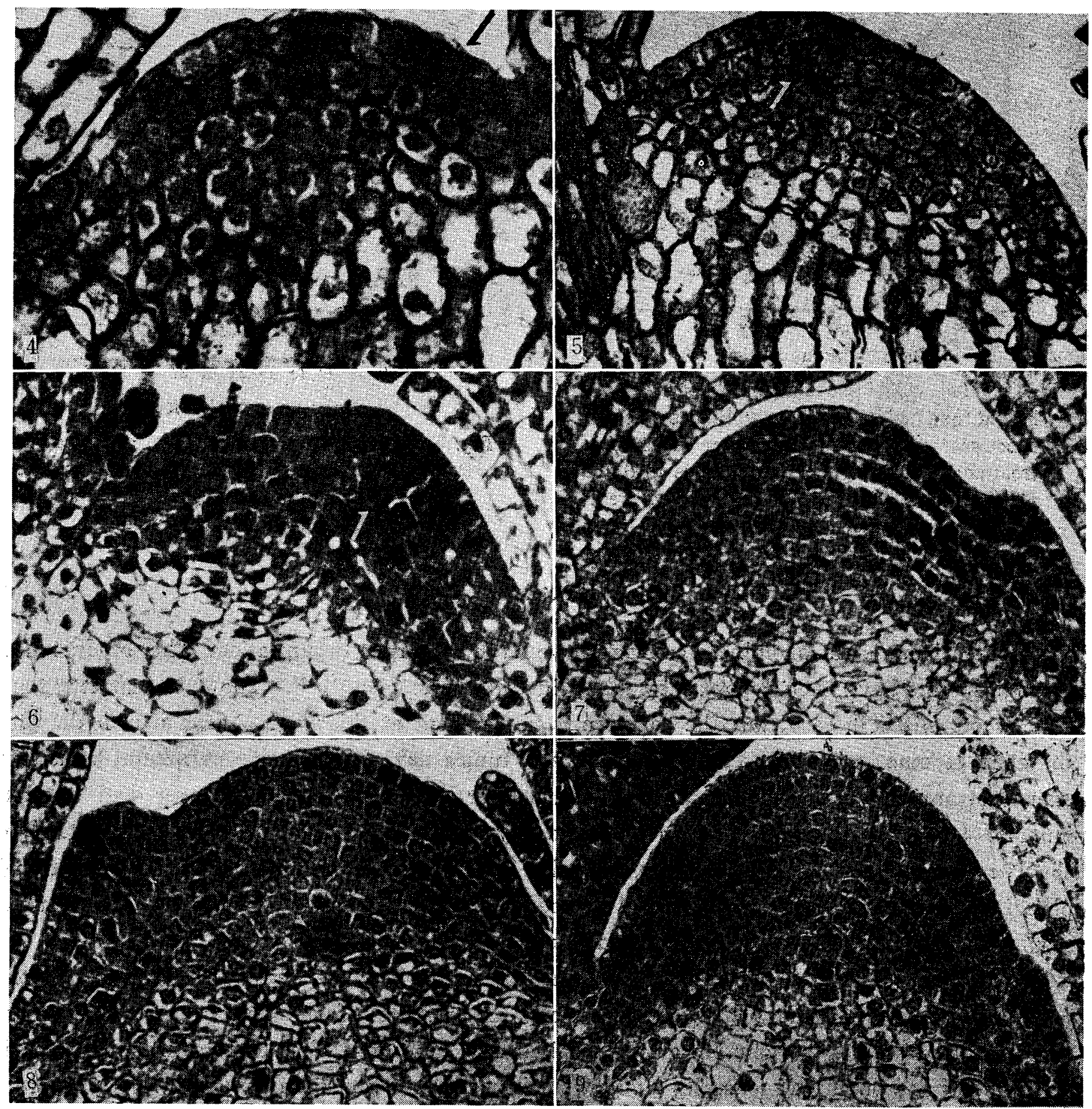

Fig. 4. Apex after $24 \mathrm{hr}$ hydration. One or two tunica layers are observed. From the 2 nd layer, lst leaf is initiated by periclinal division. The cells at subapical region are elongated. The arrow shows heavy stained cells. $\times 600$

Fig. 5. Apex after $48 \mathrm{hr}$ hydration. The cells become smaller while the number of cells increases. The 3 rd leaf is initiated from 2nd layer of the tunica. The cells at subapical region are still elongate. The arrow shows 3rd leaf initial. $\times 600$

Fig. 6. Apex after 3 days hydration. The 5 th leaf initiation could be observed by periclinal division at 3 rd layer (arrow). The cells at subapical region become flat in shape. $\times 700$

Fig. 7. 8 days after seed hydration. 6 th leaf is also initiated from 3rd tunica layer. The zonation becomes clear. $\times 500$

Fig. 8. 26 days after seed hydration. The number of tunica layer increases, possesses 4 to 5 layers. The leaf primordium is also initiated at the 3 rd layer. $\times 600$

Fig. 9. 3 days after the end of chilling treatment. The height increases, and the cells of the subapical region are elongate. The number of tunica layers possess the maximum of 6 layers. $\times 600$ 


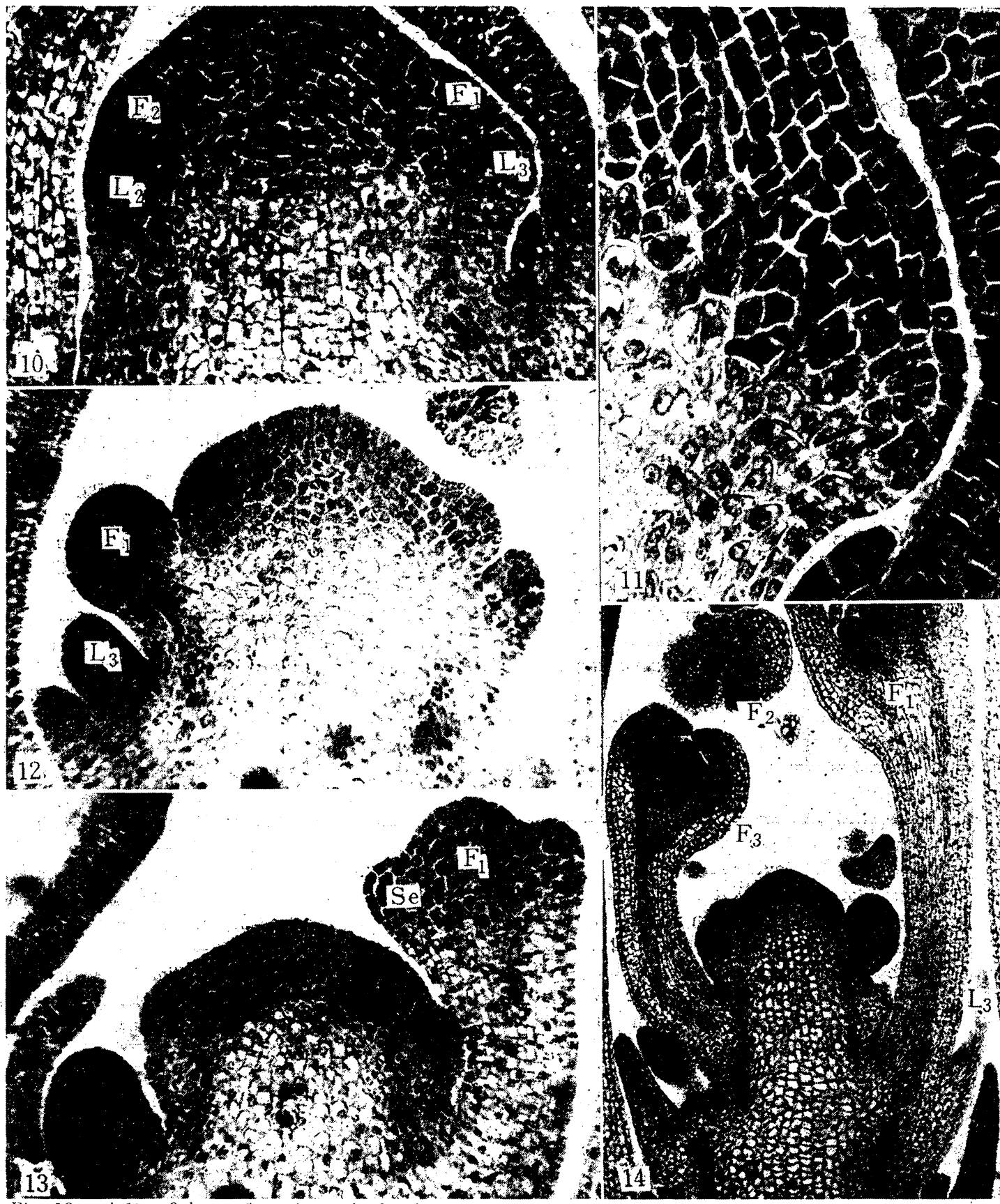

Fig. 10 and 11. 9 days after the end of chilling treatment (Fig. 11 was enlargement of the right of Fig. 10). Volume of an apex increases, and the cells of subapical region are more elongated. lst floral primordium is formed at the inner part of the apex, whereas the leaf is also from the 3rd layer. Upper arrow pointed the heavily stained cells shows where the flower primordium is initiated. Lower arrow shows the weakly stained cells. Where the leaf (bract) primordium is initiated; $F_{1}, F_{2}$, lst and 3 nd floral initials respectively; $L_{2}, L_{3}, 2$ nd and 3rd leaf (bract) initials from the terminal respectively. $\times 180$ and 800

Fig. 12. 11 days after the end of chilling treatment; $F_{1}$, lst floral initial; $\mathrm{L}_{3}$, 3rd leaf initial from the terminal $\times 150$

Fig. 13. 13 days after the end of chilling treatment; Se, sepal; $F_{1}$, lst floral initial. $\times 120$

Fig. 14. 15 days after chilling treatment ; $F_{1}, F_{2}, F_{3}, L_{3}$, are the same as Fig. $10 \times 80$ 
also reported the the same results in Phalaenopsis and other kinds of Orchids ${ }^{(16)}$.

Upper internodes elongation occur at the time when tunica layers increased from 5 to 6 layers. The earliest symptom of the bolting is the occnrrence of cell elongation at the subapical region. This elongation is quite obvious and has been studied by Philipson ${ }^{(11)}$.

As a result of the anatomical observation discussed above, the bolting occurrs before the initiation of first floral primordium.

\section{Acknowledgement}

The author wishes to express my thanks to Professor H. Torikata and Dr. M. Sisa for suggesting this investigations. Thanks are also due to Professor M. Shimizu for some valuable suggestions.

\section{Literature cited}

1. Arlette Nougarede, E.M. Gifford, J.R. and PIERRE RONDET. 1965. Cytohistological studies of the apical meristem of Amaranthus Retroflexus under various photoperiodic regimes. Botan. Gaz. 126 : 248-298.

2. GIFFORD, E.M., J.R. 1950. The structure and development of the shoot apex in certain woody Ranales. Amer. Jour. Bot. 37 : 595-611.

3. and H.B. TEPFER. 1961. Ontogeny of the inflorescence in Chenopodium album. Amer. Jour. Bot. $48: 657-667$.

4. — and - 1962. Histochemical and autoradiographic studies of floral induction in Chenopodium album. Amer. Jour. Bot. 49: $706-714$.

5. MARUSHige, Y. 1965 a. Ontogeny of the Vegetative and the Reproductive Apices in Pharbitis nil Chois. I. Development of the Vegetative Apex. Bot. Mag. Tokyo $78: 353-359$.

6. $1965 \mathrm{~b}$. Ontogeny of the Vegetative Apices in Pharbitis nil Chois. II. Development of the Terminal flower bud. ibid $78: 397-406$.

7. - $1965 \mathrm{c}$. Ontogeny of the Vegetative and the Reproductive Apices in Pharbitis nil Chois. III. Development of Axillary Buds. ibid $78: 407-411$.

8. Miller,H.A., and R.H.WeTMORE. 1946. Studies in the developmental anatomy of Phlox drummondii Hook. III. The apices of the mature plant. Amer. Jour. Bot. $33: 1-10$.

9. Millington W.F., and EMMA L. FISK 1956. Shoot development in Xanthium Pensylvanicum.
I. The vegetative plant. Amer. Jour. Bot. 43: 655.

10. Opatrna, J., F.Seidlova and K.Benes. 1964. The anatomy of the shoot apex of Wheat (Triricum awstivum L.) during transition from the vegetative to the reproductive state and the determination of the primordia. Biologia Plantarum (Praha). 6 : 219-225.

11. PHILIPSON, W.R.I. 1946. Studies in the development of the inflorescence. I. The capitulum of Bellis perennis L. Ann. Bot. N.S. $10: 257$ -270 .

12. Satina, S., A.F. Blakeslee and A.G. Aery. 1940. Demonstration of the three germ layers in the shoot apex of Datura by means of induced polyploidy in periclinal chimeras. Amer. Jour. Bot. $27: 895-905$.

13. SHWABE, W.W. 1959. Some effects of environment and hormone on reproductive morphogenesis in the Chrysanthemum. Jour. Linn. Soc. London. $56: 254-261$.

14. TEPFER, S. S. 1953. Floral anatomy and ontogeny in Aquilegia Formosa var. truncata and Ranunculus repens. Univ. Calif. Publ. Bot. 25 : 513-648.

15. WANG, P. J. 1966. Studies on the flower bud differentiation in To-pe-tsai. (Brassica chinensis L.) Nagoya Univ. M.S. thesis : 1-25.

16. —— - and H.TORIKATA. 1968. Seed formation and sterile culture of the orchids. 247263. Seibundo shinkoshya press (Tokyo) 
土白菜 (Brassica chinensis cultivar To-pe-tsai) の発育および分化にと もなら Shoot apex の構造変化

\author{
王 博 仁 \\ (名古屋大学農学部)
}

土白菜の種子から開花に至るまでの茎頂生長点の変化 を視察した結果，次のようなことがわかった。Tunica 層は種子内にすでに 1 層形成されており, 第 3 葉が発生 する時には 2 層, 第 10 葉から 4 ～層になる。花芽分化 が起る直前に 1 時 6 層に達するがすぐ 3 層にまで減少 し, 同時に生長点は肥大して, 腰高になる。第 1 花房は
終葉より数えて， 2 または 3 節目の節位に発生する。 第 $1 \sim 4$ 葉は Tunica 2 層より, 第 5 葉から終葉は 3 層, 花芽は一貫して第 4 層から発生する。 抽苔は亜頂端部の細胞が伸長することから始まりここ の伸長の始まりは Tunica が 5 層から 6 層になった時, 即ち第 1 花房が発生する以前に起こる。 